\title{
A Rare Cause of Hemoptysis: Oropharyngeal Leech
}

\author{
Nadir Bir Hemoptizi Nedeni: Orofaringeal Sülük
}

(1) İdris Çıldır

Karaman State Hospital, Clinic of Otolarangology, Karaman, Turkey

Cite this article as: Çıldır İ. A Rare Cause of Hemoptysis: Oropharyngeal Leech. Turkiye Parazitol Derg 2020;44(1):61-3.

\begin{abstract}
We report the case of a 33-year-old patient who presented with dyspnea and hemoptysis due to an oropharyngeal leech infestation. The patient was a shepherd and his detailed history revealed that he had been drinking water from natural springs. In the examination, a vivid dark green colored foreign body moving towards the nasopharynx and hypopharynx was detected in the oropharynx. The leech was removed under local anesthesia by gently grasping with the help of a long clamp. It should be noted that leeches are common in rural water sources and they can cause severe morbidity and even mortalities due to serious complications such as severe anemia and airway obstructions. A thorough oral and oropharyngeal examination will be sufficient to identify such cases, indicating the importance of physical examination in patients that present with otherwise unexplained airway obstruction and hemoptysis.
\end{abstract}

Keywords: Leech, hemoptysis, respiratory foreign body

\section{ÖZ}

Bu çalışmada, orofaringeal sülüğe bağlı dispne ve hemoptizi şikayeti ile başvuran 33 yaşında bir hasta sunuldu. Hasta bir çobandı ve ayrıntılı özgeçmişinde doğal kaynaklardan su içme öyküsü bulunuyordu. Muayenede orofarinkste, nazofarinks ve hipofarinks yönüne doğru hareket eden canlı koyu yeşil renkli yabancı cisim tespit edildi. Sülük lokal anestezi altında uzun bir klemp yardımıyla yardımıyla hafifçe tutularak çıkarıldı. Sülüklerin kırsal su kaynaklarında yaygın olduğu ve şiddetli anemi ve havayolu tıkanıklığ gibi ciddi komplikasyonlar nedeniyle ciddi morbidite ve hatta ölümlere neden olabileceği bildirilmiştir. Açılanamayan hava yolu tıkanıklığı ve hemoptizi ile başvuran hastalarda fizik muayenenin önemli olduğunu gösteren bu tür olguları belirlemek için ayrıntılı bir oral ve orofaringeal muayene yeterli olacaktır.

Anahtar Kelimeler: Sülük, hemoptizi, solunum yolunda yabancı cisim

\section{INTRODUCTION}

Leeches are blood-sucking hermaphrodite parasites that are classified in the phylum Annelida of the class Hirudinea $(1,2)$. Leech infestations often occur with aquatic leeches and are more common in the rural regions of Asia, the Mediterranean countries and Africa (3). Aquatic leeches may enter the body through oral or nasal routes when individuals wash and drink, while the urogenital route is also observed when individuals swim or bathe in infested water (4). Leech saliva contains also anesthetic agents; therefore, the host often does not perceive leech as a foreign body, they may not even feel the entity even during attachment. Despite this, depending on the location they have attached to, leaches may cause various symptoms such as continuous bleeding, hematemesis, nosebleeds, hemoptysis and cough $(4,5)$. Stridor and even death may occur if the leech reaches the larynx and trachea.

\section{CASE REPORT}

A 33-year-old male patient who was admitted to the emergency outpatient clinic with complaints of hemoptysis was referred to the ear, nose and throat (ENT) department with a preliminary diagnosis of oropharyngeal leech after he was examined by the emergency physician. In his detailed history, the patient stated that he was a shepherd and often drank from the spring water in the mountains. He said that blood had been coming from his mouth for the last 3-4 days, he was snoring, and also had weakness, dry coughs and occasional breathing difficulties. In the

Received/Geliș Tarihi: 25.11.2019 Accepted/Kabul Tarihi: 13.12.2019

Address for Correspondence/Yazar Adresi: Idris Çıldır MD, Karaman State Hospital, Clinic of Otolarangology, Karaman, Turkey

Phone/Tel: +90 5057898974 E-mail/E-Posta: idriscildir@gmail.com ORCID ID: orcid.org/0000-0003-3615-8734 
ENT examination, a vivid dark green colored foreign body moving towards the nasopharynx and hypopharynx was detected in the oropharynx (Figure 1).

The patient was admitted to the clinic with a preliminary diagnosis of leech. Laboratory tests revealed a hemoglobin value of $8.5 \mathrm{~g} / \mathrm{dL}$. The leech located in the oropharynx was removed under local anesthesia by gently grasping with the help of a long clamp (Figure 2, 3).

After the procedure, the oropharynx was controlled and the minimal bleeding was stopped by applying pressure (Figure 4). The patient was discharged with a favorable general condition and was referred to the hematology outpatient clinic for anemia evaluation.

\section{DISCUSSION}

Leeches can generally pass into the human body via the excretory orifices of individuals who drink or bathe in infested waters (4). Because of this mode of transmission, nearly all cases have been reported from underdeveloped countries where the use of safe water is a common problem, particularly in rural areas (6). Clinical features are variable and depend mostly on the site of attachment. A meta-analysis by Saki and colleagues reviewed 28 leech infestation cases from Iran and 62 cases from the other countries. The majority of the cases were reported from Near Eastern countries such as Iran, Pakistan, Israel, Syria and Turkey. Reported cases had a wide age distribution (2 to 70 years) and were mostly associated with drinking from or swimming in spring waters. It was found that upper respiratory tract infestation was a common site and related symptoms such as cough, bloody sputum production, frank hemoptysis, and dyspnea were common (7). The most common clinical feature of leech parasites is nasal infestation and recurrent unexplained epistaxis (8). In a 19-patient study conducted between 2012 and 2016, it was shown that all patients (12 nasal, 6 nasopharynx, 1larynx) presented with at least one of the following findings: epistaxis, hemoptysis, coughing, foreign body sensation at the site, and bloody stool (9). In our case, hemoptysis and shortness of breath due to leech

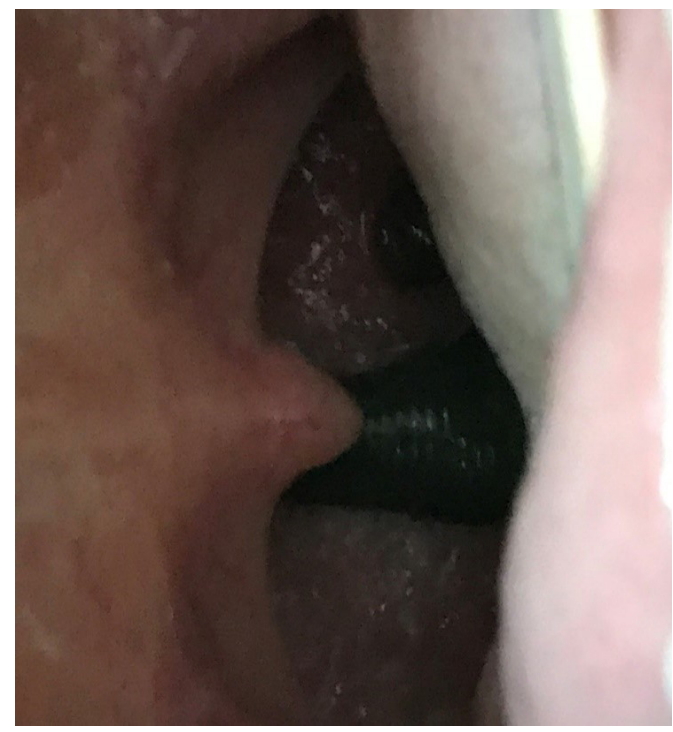

Figure 1. The appearance of the leech during oropharyngeal examination attachment to the oropharyngeal region and mild anemia were observed.

When localized in the oropharynx, leech infestation may simulate the symptoms of angioedema. Symptoms of mechanical obstruction, including nasal obstruction, dysphagia, dysphonia

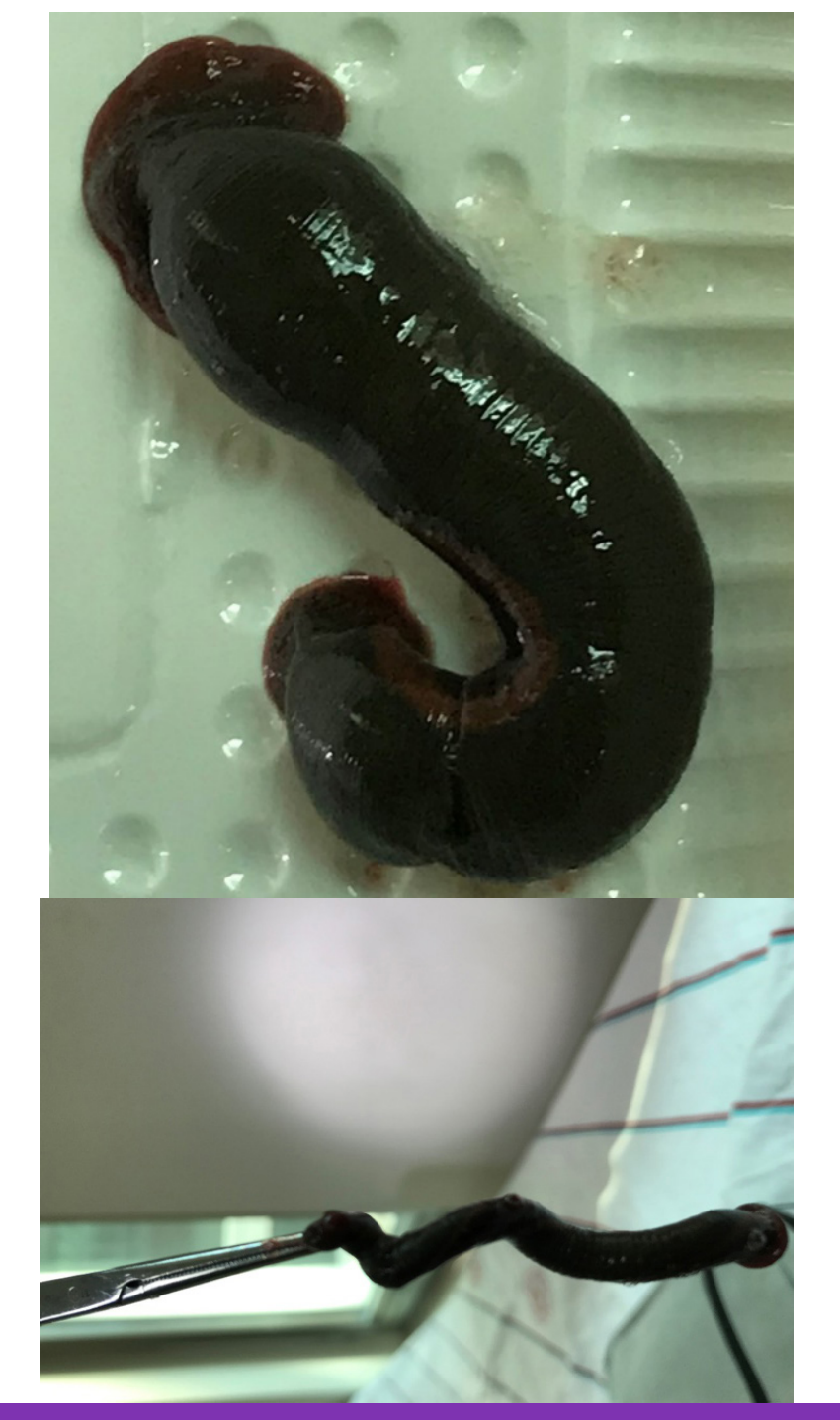

Figure 2, 3. İmage of leech after removal

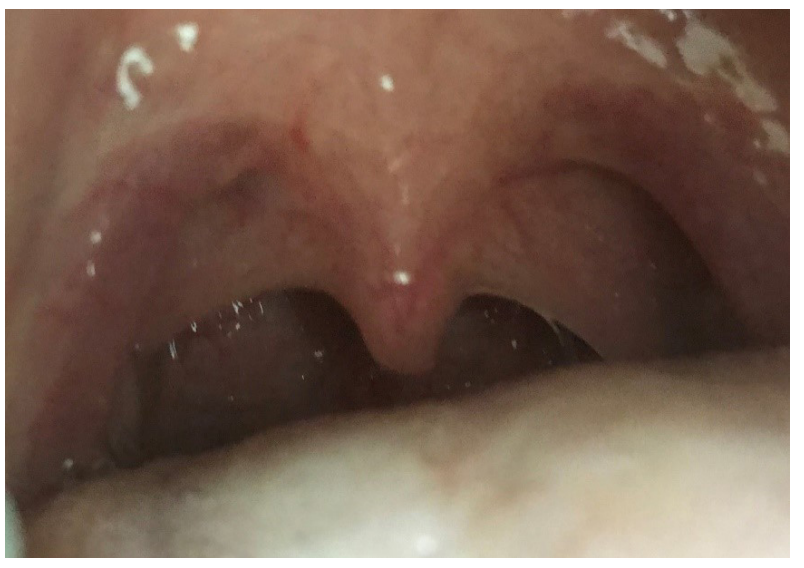

Figure 4. View of the oropharynx after the procedure 
or dyspnea can progress over time, since the leech will grow with feeding (10). Such cases in the airways require urgent intervention since hypoxia may be a real possibility that could further lead to severe obstructions and even death (11). For instance, Kunduracioğlu et al. (12) reported a case of almost complete obstruction of the rima glottis in a 77-year-old male patient, and Güloğlu et al. (13) reported a case of a 23-year-old male patient that had died due to respiratory obstruction caused by a leech located just below the epiglottis.

Severe or even life-threatening anemia is a common finding in patients with leech infestation (14). In the literature, cases of leech infestation with severe anemia that required blood transfusions have been reported $(2,14,15)$. Cundall et al. (14) reported leech infestations in six cases; three had severe anemia and one had died. In a case reported by Ağın et al. (15), hemoglobin level was shown to have decreased to $3.8 \mathrm{~g} / \mathrm{dL}$ and urgent blood transfusions were required.

In the literature, in addition to mechanical separation/removal, additional treatment models including superficial administration of local anesthetics or hypertonic saline, have been reported $(1,2)$. For the removal of nasopharyngeal leeches, $5 \%$ cocaine or $4 \%$ lidocaine solution was injected directly into the leech, causing paralysis (4). In addition, physiological saline, nit, turpentine oil and alcohols was reported to assist in the separation of leeches (4). In our case, the leech located in the oropharynx was removed under local anesthesia by gentle grasping and pulling with a long clamp.

\section{CONCLUSION}

Hirudiniasis should be part of the differential diagnosis in patients presenting with unexplained hemoptysis or anemia, especially if they live in less developed rural areas where clean drinking water is not always available. Careful examination of the upper respiratory tract and digestive tract may provide early detection of leech infestation. Early diagnosis and treatment are important in preventing fatal complications due to long-term leech exposure. Because of the risk of contamination, people living in endemic areas should be educated to avoid drinking water directly from natural sources and they should be encouraged to use boiled and/ or filtered water.

\section{* Ethics}

Informed Consent: Informed consent was obtained.

Peer-review: Internally peer reviewed.
Financial Disclosure: The author declared that this study received no financial support.

\section{REFERENCES}

1. White G. Leeches and leech infestation. Manson's tropical diseases, 20th edn. Saunders, London. 1998:1523-5.

2. El-Awad ME, Patil K. Haematemesis due to leech infestation. Annals of Tropical Paediatrics. 1990;10:61-2.

3. Walker DH, Guerrant RL and Weller PF. Essentials of tropical infectious diseases. Churchill Livingstone, 2001. ISBN 0443079099.

4. Bilgen C, Karci B and Uluöz Ü. A nasopharyngeal mass: leech in the nasopharynx. International Journal of Pediatric Otorhinolaryngology 2002;64:73-6.

5. Chen WC, Chien CY, Yang CH, Li JH, Hwang CF. Nasal leech infestation: report of seven leeches and literature review. European Archives of OtoRhino-Laryngology 2010;267:1225-9.

6. Solomon E. Leech--an unusual cause of (laryngo-tracheal) obstruction. Ethiopian Medical Journal 1991;29:141-2.

7. Saki N, Rahim F, Nikaghlagh S and Saki G. Meta analysis of the leech as a live foreign body: detection, precaution and treatment. Pakistan Journal of Biological Sciences 2009;12:1556-63.

8. Chen WC, Chien CY, Yang CH, Li JH and Hwang CF. Nasal leech infestation: report of seven leeches and literature review. European Archives of OtoRhino-Laryngology: Official journal of the European Federation of OtoRhino-Laryngological Societies (EUFOS) 2010;267:1225-9.

9. Harun K. Management of upper airway leech infestations. Ear Nose Throat Journal 2019:145561319860527.

10. Aluiz C, Yasar NF, Uzun O and Polat E. Oropharyngeal leech infestation: A Case Report. Firat Tip Dergisi. 2013; 18.

11. Kuehnemund M, Bootz F. Rare living hypopharyngeal foreign body. Head Neck 2006;28:1046-8.

12. Kunduracıoğlu A, Karasu I, Afrashi A, Özsöz A, Çakan A, Aksel N. Larinkste sülük infestasyonuna bağlı hemoptizi. Solunum Derg 2009;11:134-6.

13. Güloğlu C, Al B, Özhasenekler A, Güllü N, Aldemir M. Üst solunum yolu obstruksiyonu, burun kanaması ve kronik aneminin nadir bir sebebi olarak sülük: İki olguluk deneyimimiz. Tıp Araştırmaları Dergisi 2004;2:45-8.

14. Cundall DB, Whitehead SM, Hechtel FO. Severe anaemia and death due to the pharyngeal leech Myxobdella africana. Transactions of the Royal Society of Tropical Medicine and Hygiene 1986;80:940-4.

15. Ağin H, Ayhan FY, Gülfidan G, Cevik D, Derebaşi H. Severe anemia due to the pharyngeal leech Limnatis nilotica in a child. Turkiye Parazitol Derg 2008;32:247-8. 